\title{
Integrated genomic study of quadruple-WT GIST (KIT/PDGFRA/SDH/RAS pathway wild-type GIST)
}

Margherita Nannini ${ }^{1}$, Annalisa Astolfi ${ }^{2}$, Milena Urbini ${ }^{2}$, Valentina Indio ${ }^{2}$, Donatella Santini ${ }^{3}$, Michael C Heinrich ${ }^{4}$, Christopher L Corless ${ }^{5}$, Claudio Ceccarelli ${ }^{3}$, Maristella Saponara ${ }^{2}$, Anna Mandrioli ${ }^{1}$, Cristian Lolli ${ }^{1}$, Giorgio Ercolani ${ }^{6}$, Giovanni Brandi ${ }^{1}$, Guido Biasco ${ }^{1,2}$ and Maria A Pantaleo ${ }^{1,2^{*}}$

\begin{abstract}
Background: About 10-15\% of adult gastrointestinal stromal tumors (GIST) and the vast majority of pediatric GIST do not harbour KIT or platelet-derived growth factor receptor alpha (PDGFRA) mutations (J Clin Oncol 22:3813-3825, 2004; Hematol Oncol Clin North Am 23:15-34, 2009). The molecular biology of these GIST, originally defined as KIT/ PDGFRA wild-type (WT), is complex due to the existence of different subgroups with distinct molecular hallmarks, including defects in the succinate dehydrogenase (SDH) complex and mutations of neurofibromatosis type 1 (NF1), BRAF, or KRAS genes (RAS-pathway or RAS-P).

In this extremely heterogeneous landscape, the clinical profile and molecular abnormalities of the small subgroup of WT GIST suitably referred to as quadruple wild-type GIST (quadruple $\mathrm{WT}^{\mathrm{WT}}$ or KIT $T^{\mathrm{WT}} / \mathrm{PDGFRA} \mathrm{W}^{\mathrm{WT}} / \mathrm{SD} \mathrm{H}^{\mathrm{WT}} / \mathrm{RAS}$-P $\mathrm{WT}$ ) remains undefined. The aim of this study is to investigate the genomic profile of KIT ${ }^{\mathrm{WT}} / P D G F R A^{W T} / S D H^{W T} / R A S-P^{W T}$ GIST, by using a massively parallel sequencing and microarray approach, and compare it with the genomic profile of other GIST subtypes.
\end{abstract}

Methods: We performed a whole genome analysis using a massively parallel sequencing approach on a total of

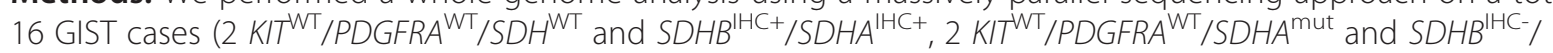
SDHA ${ }^{\text {IHC- }}$ and 12 cases of KIT ${ }^{\text {mut }}$ or PDGFRA ${ }^{\text {mut }}$ GIST). To confirm and extend the results, whole-genome gene expression analysis by microarray was performed on 9 out 16 patients analyzed by RNAseq and an additional 20 GIST patients ( 1 KIT $T^{\mathrm{WT}} /$ PDGFRA ${ }^{\mathrm{WT}}$ SDHA ${ }^{\text {mut }}$ GIST and $19 \mathrm{KIT}^{\text {mut }}$ or PDGFRA ${ }^{\text {mut }}$ GIST). The most impressive data were validated by quantitave PCR and Western Blot analysis.

Results: We found that both cases of quadruple $\mathrm{WT}^{\mathrm{WT}}$ GIST had a genomic profile profoundly different from both either KIT/PDGFRA mutated or SDHA-mutated GIST. In particular, the quadruple ${ }^{\mathrm{WT}}$ GIST tumors are characterized by the overexpression of molecular markers (CALCRL and COL22A1) and of specific oncogenes including tyrosine and cyclin- dependent kinases (NTRK2 and CDK6) and one member of the ETS-transcription factor family (ERG).

(Continued on next page)

\footnotetext{
* Correspondence: maria.pantaleo@unibo.it

${ }^{1}$ Department of Specialized, Experimental and Diagnostic Medicine,

Sant'Orsola-Malpighi Hospital, University of Bologna, Via Massarenti 9, 40138

Bologna, Italy

2"Giorgio Prodi" Cancer Research Center, University of Bologna, Bologna, Italy

Full list of author information is available at the end of the article
} 
(Continued from previous page)

Conclusion: We report for the first time an integrated genomic picture of KIT $T^{W T} / P D G F R A^{W T} / S D H^{W T} / R A S-P^{W T}$ GIST, using massively parallel sequencing and gene expression analyses, and found that quadruple ${ }^{W T}$ GIST have an expression signature that is distinct from SDH-mutant GIST as well as GIST harbouring mutations in KIT or PDGFRA. Our findings suggest that quadruple ${ }^{\mathrm{WT}}$ GIST represent another unique group within the family of gastrointestintal stromal tumors.

Keywords: Gastrointestinal stromal tumors (GIST), Wild-type, KIT, PDGFRA, Succinate dehydrogenase, SDHA, RAS, Quadruple ${ }^{\mathrm{WT}}$

\section{Background}

About 10-15\% of adult gastrointestinal stromal tumors (GIST) and the vast majority of pediatric GIST do not harbour $K I T$ or platelet-derived growth factor receptor alpha (PDGFRA) mutations [1,2]. These GIST were originally defined as KIT/PDGFRA wild-type (KIT $\left.{ }^{\mathrm{WT}} / P D G F R A^{\mathrm{WT}}\right)$ and generally are less sensitive to tyrosine-kinase inhibitors [3-5]. Their molecular biology is heterogeneous as evidence by the existence of different subgroups with distinct molecular abnormalities (Figure 1). KIT ${ }^{\mathrm{WT}}$ / PDGFRA ${ }^{\mathrm{WT}}$ GIST can be divided into two main groups according to the succinate dehydrogenase subunit $\mathrm{B}$ (SDHB) immunohistochemical status (IHC): $S D H B$ positive $\left(S D H B^{\mathrm{IHC}+}\right)$, or type $1 \mathrm{GIST}$ which, includes neurofibromatosis type 1 (NF1)-mutated GIST and some sporadic $K I T^{\mathrm{WT}} / P D G F R A^{\mathrm{WT}}$ GIST. The second group of $K I T^{\mathrm{WT}} / P D G F R A^{\mathrm{WT}}$, called as type 2 GIST, is characterized by a lack of $S D H B$ protein expression $\left(S D H B^{\mathrm{IHC}-}\right)$. In some cases $S D H B^{\mathrm{IHC}-}$ is due to germline and/or de novo mutations of any of the four $S D H$ subunits ( $S D H A^{\text {mut }}$ ) [6-8]. The $S D H B^{\mathrm{IHC}-}$ includes additional subgroups that can be distinguished on the basis of the SDHA IHC status, which strictly correlates with the presence of $S D H A$ inactivating mutations $\left(S D H A^{\mathrm{mut}}\right)$ [9-16]. In particular, $S D H B^{\mathrm{IHC}-} / S D H A^{\mathrm{IHC}-}$ GIST include a subgroup of young adult women patients with a well defined clinical and biological profile, generally characterized by the gastric primary tumour localization, a predominantly mixed epithelioid and spindle cell morphology, diffuse IHC positivity for KIT and discovered on gastrointestinal stromal tumours 1 (DOG1), frequent lymph node metastases, and an indolent course of disease even if metastasis is present [17]. Moreover, they are characterized by overexpression of the insulin growth factor 1 receptor $(I G F 1 R)$ [18-21]. On the contrary, $S D H B^{\mathrm{IHC}-}$, but $S D H A^{\mathrm{IHC}+}$ subgroup include 1) cases of syndromic GIST arising from the Carney-Stratakis Syndrome (CSS), that are characterized by $S D H B, S D H C$ or $S D H D$ inactivating mutations $\left(S D H B^{\text {mut }}, S D H C^{\text {mut }}\right.$, or $S D H D^{\text {mut }}$ ); and 2) cases of Carney Triad (CT), that lack $S D H x$-mutations [6,22-24]. More rarely, $S D H B^{\mathrm{IHC}-} / S D H A^{\mathrm{IHC}+}$ subgroup may include sporadic $K I T^{\mathrm{WT}} / P D G F R A^{\mathrm{WT}}$ GIST characterized by $S D H B,-C$ or $D$ mutations (most of them germline, and in few cases by SDHA mutations), arising mainly from the stomach, with a lesser female prevalence, but histologically similar to $S D H A^{\mathrm{IHC}-}$ GIST [15].

The $S D H B^{\mathrm{IHC+}}$ subgroup includes cases of NF1-mutated GIST, that are commonly intestinal, multifocal and have an IGF1R negative staining, and also sporadic $K I T^{\mathrm{WT}} /$ PDGFRA ${ }^{\mathrm{WT}}$ GIST, arising in the adult from any part of gastrointestinal tract $[15,21,25]$. In about $15 \%$ of cases of sporadic KIT ${ }^{\mathrm{WT}} /$ PDGFRA ${ }^{\mathrm{WT}}$ GIST there may be an activating mutation in $B R A F$ or, more rarely, $R A S$ [26-28]. Taken together, cases of $B R A F, R A S$, or $N F 1$ mutant GIST can be referred to as $R A S$-pathway (RAS-P) mutant GIST (RAS-P $\left.{ }^{\text {mut }}\right)$.

In this extremely heterogeneous landscape, the clinical profile and molecular abnormalities of the small subgroup of WT GIST suitably referred to as quadruple wild-type GIST (quadruple $\mathrm{WT}^{\mathrm{WT}}$ or $K T^{\mathrm{WT}} / P D G F R A^{\mathrm{WT}} /$ $\left.S D H^{\mathrm{WT}} / R A S-P^{\mathrm{WT}}\right)$ remains undefined [29]. The aim of this study is to investigate the genomic profile of $K I T^{\mathrm{WT}} / P D G F R A^{\mathrm{WT}} / S D H^{\mathrm{WT}} / R A S-P^{\mathrm{WT}}$ GIST, by using a massively parallel sequencing and microarray approach, and compare it with the genomic profile of other GIST subtypes.

\section{Results and discussion}

Whole-Transcriptome Paired-End RNA Sequencing and copy number analysis

Whole-Transcriptome Paired-End RNA Sequencing was performed on a total of 16 GIST samples, of which 2 were $K I T^{\mathrm{WT}} / P D G F R A^{\mathrm{WT}}$ without $S D H$-inactivating mutations and $S D H B^{\mathrm{IHC}+} / S D H A^{\mathrm{IHC+}}$ (GIST_133 and GIST_127), 2 were $K I T^{\mathrm{WT}} / P D G F R A^{\mathrm{WT}} / S D \bar{H} A^{\text {mut }}$ and $S D H B^{\mathrm{IHC}-} / S D H A^{\mathrm{IHC}-}$ (GIST_7 and GIST_10), and 12 were $K I T^{\text {mut }}$ or $P D G F R A^{\text {mut }}$. The principal component analysis showed that both GIST_133 and GIST_127 $\left(K I T^{\mathrm{WT}} / P D G F R A^{\mathrm{WT}} / S D H^{\mathrm{WT}}\right.$ and $\left.S D H B^{\mathrm{IHC}+} / S D H A^{\mathrm{IHC}+}\right)$ are characterized by a gene expression profile profoundly different from both GIST_7 and GIST_10 (KIT ${ }^{\mathrm{WT}} /$ PDGFRA ${ }^{\mathrm{WT}} / S D H A^{\text {mut }}$ and $\left.S D H B^{\mathrm{IHC}} / S D H A^{\mathrm{IHC}}\right)$, while clustering in proximity of a subset of $K I T^{\text {mut }}$ or PDGFRA $A^{\text {mut }}$ GIST (Figure 2A).

To investigate the presence of novel mutations or small ins/del in the whole coding regions of KIT and PDGFRA we analyzed whole transcriptome sequencing 

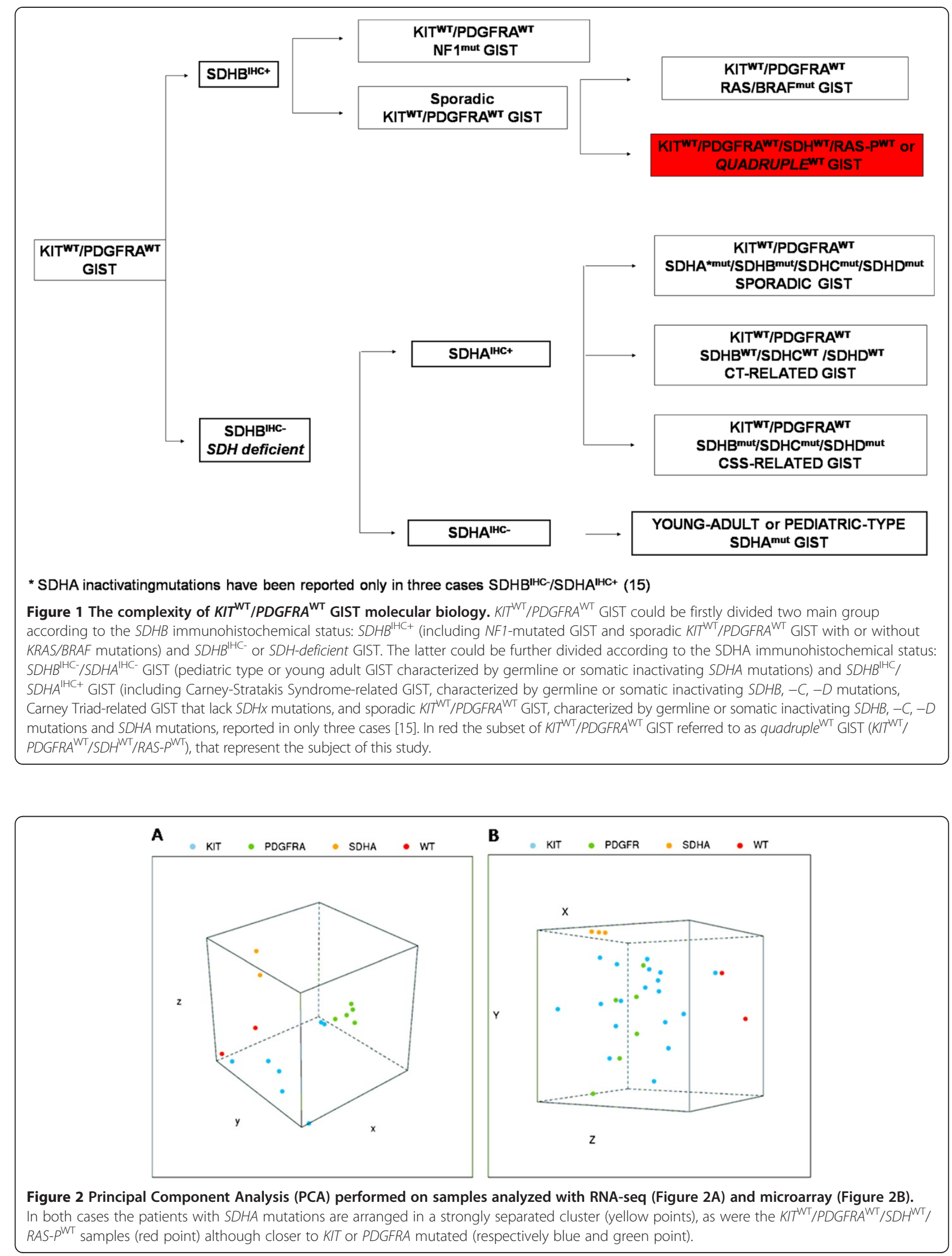
data for single nucleotide variant (SNV) and found no private or cryptic mutations. Moreover, no NF-1, BRAF, $R A S$ mutations were found by whole transcriptome sequencing. Therefore, the GIST from these two patients were $K I T^{\mathrm{WT}} / P D G F R A^{\mathrm{WT}} / S D H^{\mathrm{WT}} / R A S-P^{\mathrm{WT}}$, or quadruple $e^{\mathrm{WT}}$ GIST. Analysis of deleterious mutations from whole transcriptome sequencing did not identify any known oncogenic event or shared alteration in the two patients (Additional file 1: Table S1). Copy number analysis was performed on the two KIT ${ }^{\mathrm{WT}} / P D G F R A^{\mathrm{WT}} /$ $S D H^{\mathrm{WT}} / R A S-P^{\mathrm{WT}}$ GIST: GIST_133 showed no genomic imbalances, while GIST_127 harbors several macroscopic cytogenetic alterations, including loss of chromosome arms $14 \mathrm{q}$ and $22 \mathrm{q}$ frequently observed in KIT/PDGFRA mutated GIST.

\section{Gene expression analysis}

To confirm and extend the results, whole-genome gene expression analysis by microarray was performed on 9 out 16 patients analyzed by RNAseq and an additional 20 GIST patients $\left(1 K I T^{\mathrm{WT}} / P D G F R A^{\mathrm{WT}} S D H A^{\mathrm{mut}}\right.$ GIST and $19 K I T^{\text {mut }}$ or PDGFRA ${ }^{\text {mut }}$ GIST). The principal component analysis confirmed that both $K I T^{\mathrm{WT}} / P D G F R A^{\mathrm{WT}} /$ $S D H^{\mathrm{WT}} / R A S-P^{\mathrm{WT}}$ GIST have a genetic profile significantly different from all three $K I T^{\mathrm{WT}} / P D G F R A^{\mathrm{WT}} / S D H A^{\text {mut }}$ GIST, and cluster in close proximity to some KIT ${ }^{\text {mut }}$ GIST samples (Figure 2B). Supervised gene expression analysis revealed the presence of specific genetic signatures characterizing the different molecular subgroups of GIST (Figure 3); the $S D H A^{\text {mut }}$ group showed a gene signature mainly characterized by the over-expression of $I G F 1 R$ (p value $2.7 \times 10^{-11}$ ) and of neural markers (LHX2, KIRREL3) [30], whereas as expected, all PDGFRA ${ }^{\text {mut }}$ GIST were clearly separated from $K I T^{\text {mut }}$ GIST, especially for the expression of PDGFRA.

The quadruple ${ }^{\mathrm{WT}}\left(\right.$ KIT $T^{\mathrm{WT}} /$ PDGFRA ${ }^{\mathrm{WT}} / S D H^{\mathrm{WT}} /$ RAS-P $\left.^{\mathrm{WT}}\right)$ samples were characterized by a distinct gene expression profile (Figure 4), with 65 genes over-expressed or under-expressed ( $p$ value $<0.005$ ) compared with all the other GIST molecular subgroups. GSEA analysis of the transcriptional profile of quadruple ${ }^{\mathrm{WT}}$ tumors showed enrichment of Polycomb target genes with respect to $S D H A^{\text {mut }}$ GIST, in particular of the classes of PRC2 targets (p value 0.043) and H3K27-bound genes ( $p$ value 0.021). The function of the upregulated genes was related to cell cycle progression and MAPK signaling, ad exemplified by increased expression of SKP2, CDK6, FGF4, NTRK2). The quadruple ${ }^{\mathrm{WT}}$ GIST tumors
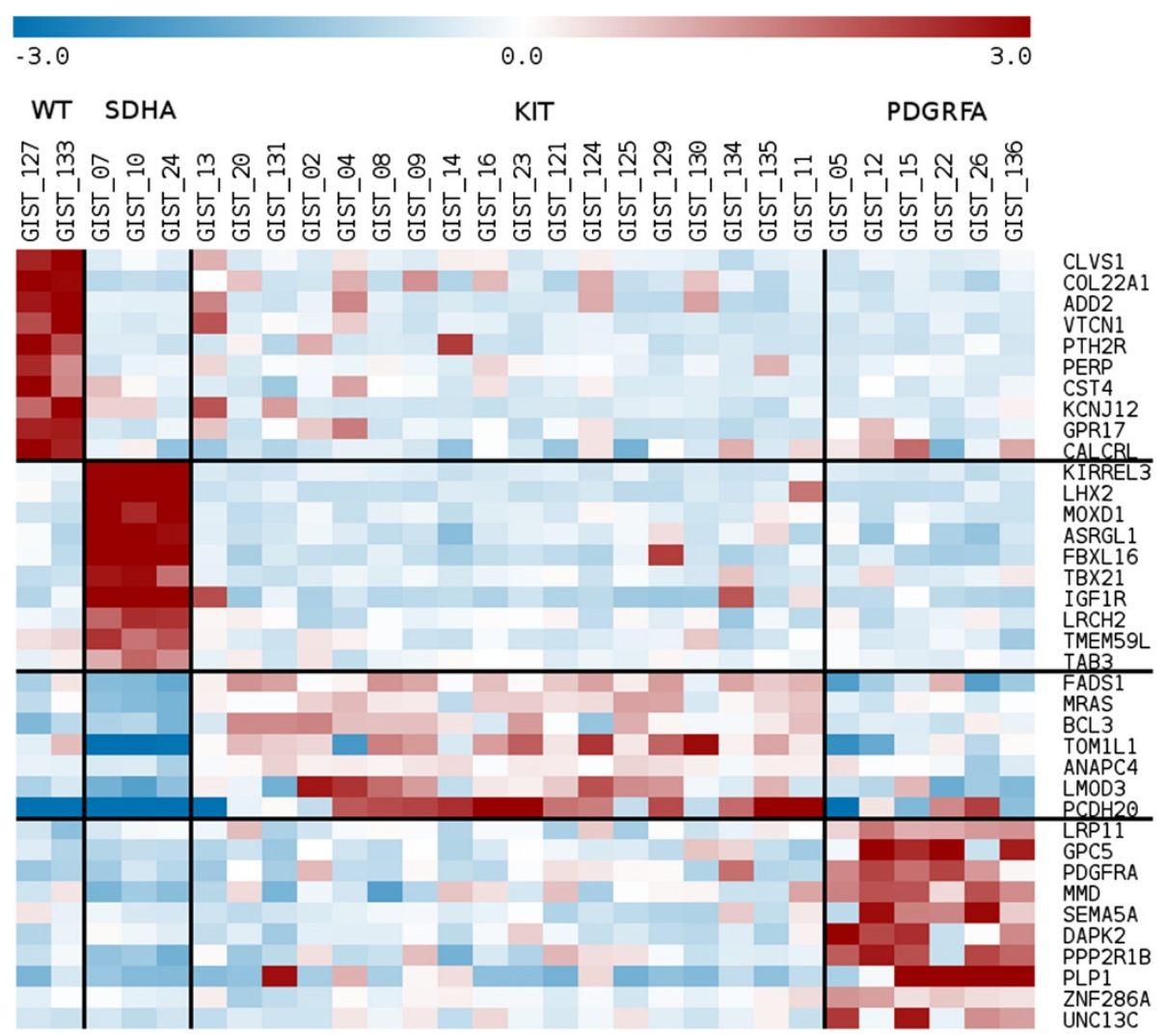

Figure 3 Representation of top-scoring genes significantly over-expressed in the four GIST classes, (KIT ${ }^{\mathrm{WT}} / P D G F R A^{\mathrm{WT}} / S D H^{\mathrm{WT}} / R_{A S}-P^{\mathrm{WT}}$, $S D H A^{\text {mut }}, K I T^{\text {mut }}$ and PDGFRA ${ }^{\text {mut }}$ ), when each of them is compared with all other cases together. 


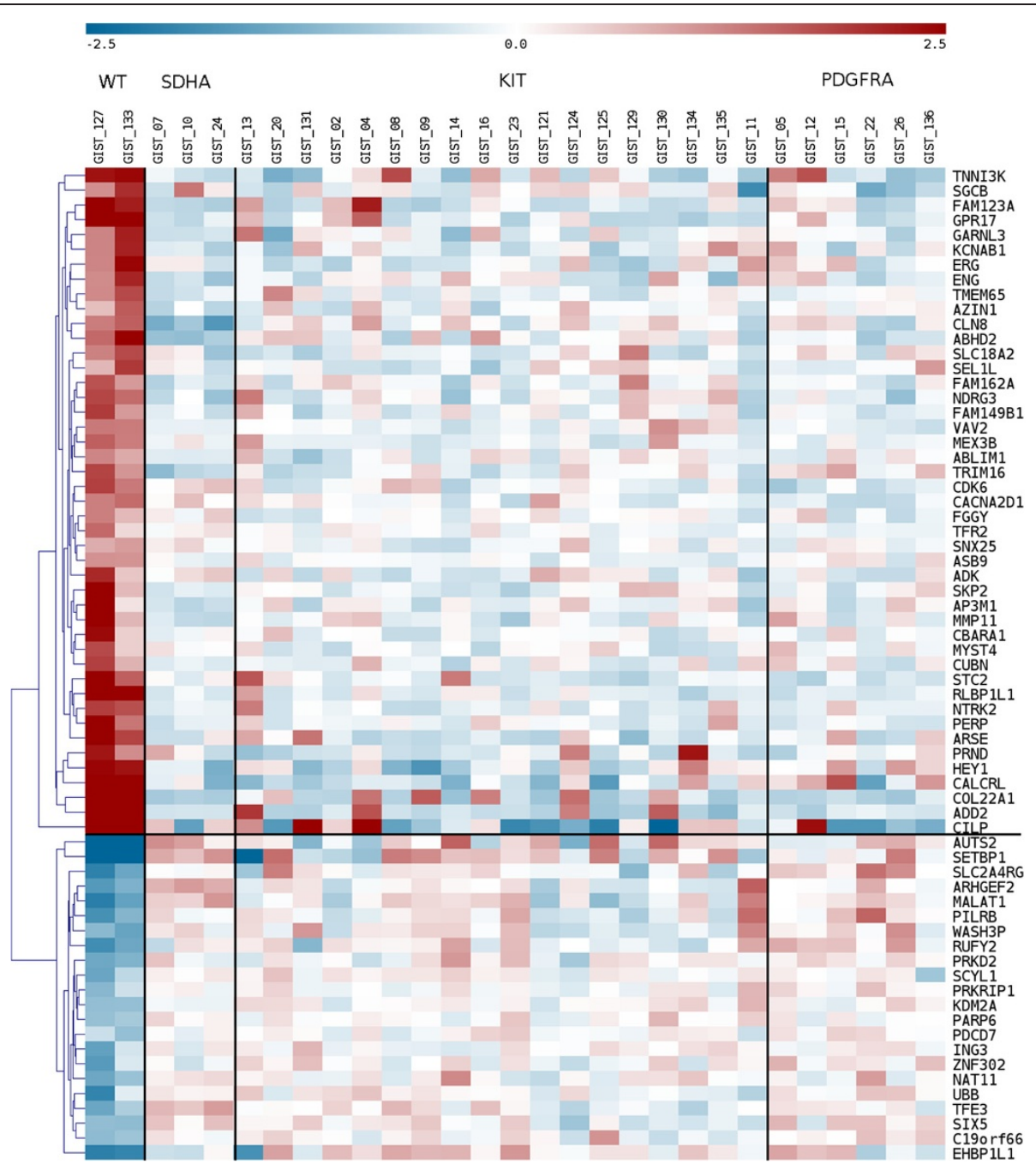

Figure 4 Unsupervised hierarchical clustering representation of differential expressed genes ( $\mathrm{P}$-value $<0.005)$ in $K I T^{\mathrm{WT}} / P D G F R A^{\mathrm{WT}} /$ $S D H^{\mathrm{WT}} /$ RAS- $\mathrm{P}^{\mathrm{WT}}$ GIST with respect to the other GIST classes (SDHx ${ }^{\mathrm{mut}}, K^{\mathrm{mut}}$ and PDGFRA ${ }^{\mathrm{mut}}$ ).

are characterized by the overexpression of molecular markers (CALCRL and COL22A1) and of specific oncogenes including tyrosine and cyclin- dependent kinases (NTRK2 and CDK6) and one member of the ETS-transcription factor family (ERG). Overexpression of CALCRL, COL22A1, NTRK2 (TrkB) and of the ETS-transcription factor ERG was confirmed by quantitative PCR, showing that only the $K I T^{\mathrm{WT}} / P D G F R A^{\mathrm{WT}} / S D H^{\mathrm{WT}} / R A S-P^{\mathrm{WT}}$ GIST subgroup expressed these molecular markers and possible therapeutic targets (Figure 5). NTRK2 protein expression level was also evaluated by Western Blot analysis and its overexpression in quadruple ${ }^{\mathrm{WT}}$ GIST was confirmed (Additional file 2: Figure S1). No mutations, gene fusions or amplifications were identified in NTRK2 and ERG.

\section{Discussion}

The pathogenesis and underlying biology of $K I T^{\mathrm{WT}} /$ PDGFRA ${ }^{\mathrm{WT}}$ with intact $S D H$ complex $\left(S D H x^{\mathrm{WT}}\right)$ and non-mutated $R A S$-pathway members $\left(R A S-P^{\mathrm{WT}}\right)$ suitably referred to as quadruple ${ }^{\mathrm{WT}}$ GIST remains undefined. In the present study, we performed a whole genome analysis using a massively parallel sequencing approach on a total of 16 GIST cases that included 2 $K I T^{\mathrm{WT}} / P D G F R A^{\mathrm{WT}} / S D H^{\mathrm{WT}}$ and $S D H B^{\mathrm{IHC}+} / S D H A^{\mathrm{IHC}+}, 2$ $K I T^{\mathrm{WT}} / P D G F R A^{\mathrm{WT}} / S D H A^{\text {mut }}$ and $S D H B^{\mathrm{IHC}-} / S D H A^{\mathrm{IHC}-}$ and 12 cases of $K I T^{\text {mut }}$ or PDGFRA ${ }^{\text {mut }}$ GIST. Notably, we found that both cases of quadruple ${ }^{\mathrm{WT}}$ GIST had a transcriptome profile profoundly different from both KIT/ PDGFRA mutated and SDHA-mutated GIST, suggesting a different molecular background underlying quadruple ${ }^{\mathrm{WT}}$ GIST. Since both cases of KIT ${ }^{\mathrm{WT}} / P D G F R A^{\mathrm{WT}} / S D H^{\mathrm{WT}}$ lacked mutations of $B R A F, R A S$ family members or $N F 1$, the GIST of these two patients was classified $K I T^{\mathrm{WT}} /$ PDGFRA ${ }^{\mathrm{WT}} / S D H^{\mathrm{WT}} / R A S-P^{\mathrm{WT}}$ or quadruple ${ }^{\mathrm{WT}}$ GIST. We further validated our data using genome wide gene expression analysis, performed on 9 cases from a previous 

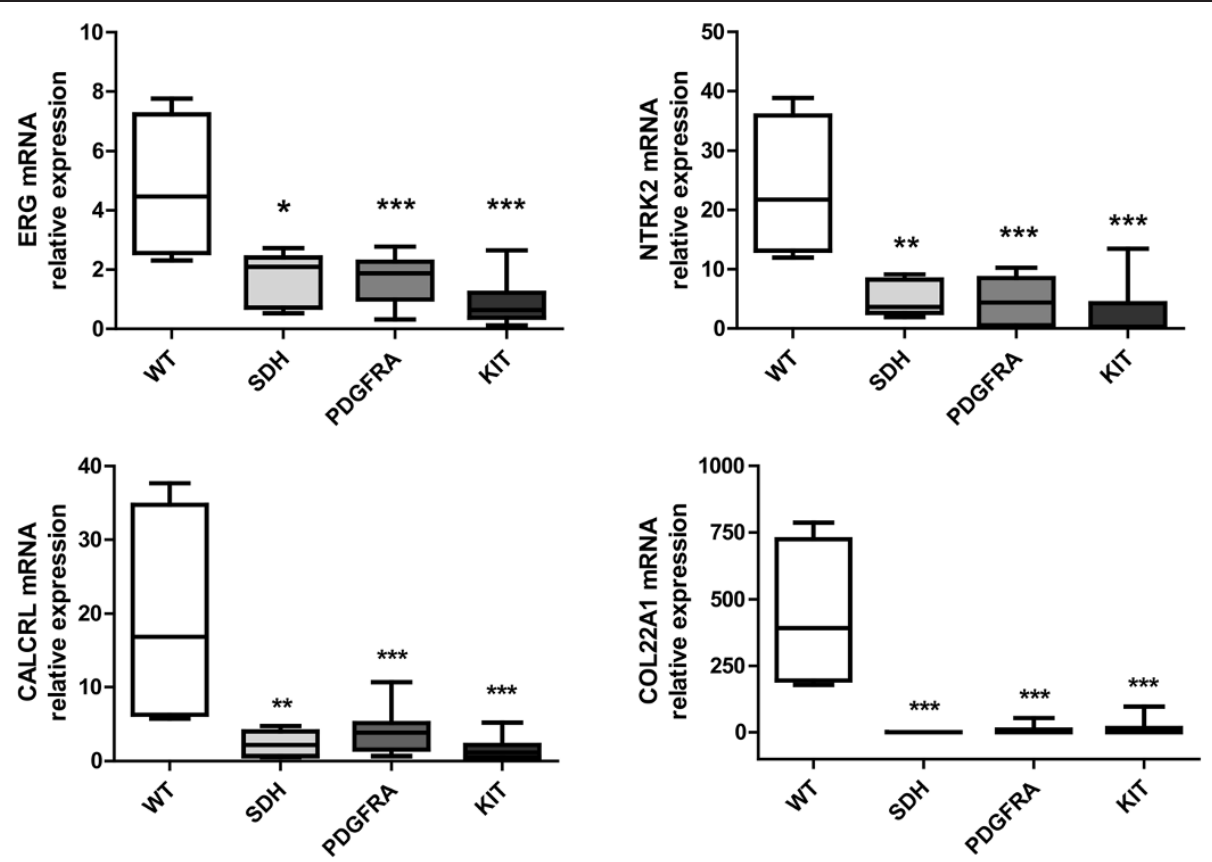

Figure 5 Quantitative PCR estimation of ERG, NTRK2, CALCRL and COL22A1 expression in GIST. Relative expression of ERG (upper left panel), NTRK2 (upper right panel), CALCRL (lower left panel) and COL22A1 (lower right panel) mRNA in the two KIT $T^{\mathrm{WT}} /$ PDDGFRA $A^{\mathrm{WT}} / S D H^{\mathrm{WT}} / R A S-P^{\mathrm{WT}}$ GIST in respect to the others molecular subgroups (4 SDHx ${ }^{\text {mut }}, 19 \mathrm{KIT}^{\mathrm{mut}}$ and 10 PDGFRA ${ }^{\text {mut }} \mathrm{GIST}$ ). Significance was estimated by the Student T-test: ${ }^{*} \mathrm{p}$-value $<0.05 ;{ }^{* *} \mathrm{p}$-value $<0.01 ;{ }^{* * *} \mathrm{p}$-value $<0.001$.

series that was expanded to include an additional 20 GIST cases $\left(1 K T^{\mathrm{WT}} / P D G F R A^{\mathrm{WT}} / S D H A^{\text {mut }}\right.$ GIST and $19 K I T^{\text {mut }}$ or PDGFRA ${ }^{\text {mut }}$ GIST). This larger analysis confirmed the unique gene expression signature of the two quadruple ${ }^{\mathrm{WT}}$ GIST compared to KIT mutant, PDGFRA mutant or SDHA-mutant GIST. Interestingly, the gene signatures of the quadruple ${ }^{\mathrm{WT}}$ GIST, which both arose in the small intestine, clustered in close proximity to a single $K I T^{\text {mut }}$ GIST sample (GIST_13). This case was a small intestine GIST of intermediate risk of relapse radically resected from a 46 year old; it harbored an exon 11 KIT point mutation (KIT exon 11 V559D). Our current sample size does not allow us to draw definitive conclusions, but we hypothesize that the intestinal origin of all three tumors may have influenced the gene signature. However, several other cases of small intestinal origin did not cluster near the cases of quadruple ${ }^{\mathrm{WT}}$ GIST. The influence of the tissue of origin on the gene signature is consistent with the recent data by Beadling et al., who described five cluster groups among 136 GIST patients (53 KIT ${ }^{\text {mut }}, 12$ PDGFRA ${ }^{\text {mut }}, 65$ adult $K I T^{\mathrm{WT}} / P D G F R A^{\mathrm{WT}}$ and 7 pediatric $K I T^{\mathrm{WT}} / P D G F R A^{\mathrm{WT}}$ ) defined by the expression patterns of 14 target genes, that were in some cases paralleled by the location of the primary tumour [31].

Using a supervised analysis, we found four gene cluster subgroups based on KIT/PDGFRA/SDH-mutational status. Due to the rarity of RAS-P mutated GIST, we did not have any cases suitable for these genomic studies. Consistent with previous reports, KIT ${ }^{\mathrm{WT}} / P D G F R A^{\mathrm{WT}} /$
$S D H A^{\text {mut }}$ GIST over-expressed IGF1R, further confirming the potential role of this receptor as a target or diagnostic marker for this specific molecular subgroup [18-21]. Moreover, as already described, the gene signature of $K I T^{\mathrm{WT}} / P D G F R A^{\mathrm{WT}} / S D H A^{\mathrm{mut}}$ GIST was largely characterized by the expression of neural-commitment transcription markers, in support of the theory that this subgroup may have a different cellular origin or may derive from interstitial cells of Cajal (ICCs) during a different differentiation step, such as from precursors of ICCs [30]. Notably, both quadruple ${ }^{\mathrm{WT}}$ GIST had a distinct gene expression signature that was separated from the $K I T^{\mathrm{WT}} / P D G F R A^{\mathrm{WT}} / S D H A^{\mathrm{mut}}$ GIST. Amongst the differentially expressed genes, it is interesting to note the over-expression of CALCRL, a G protein-coupled receptor that acts as a receptor for adrenomedullin and calcitonin gene-related peptide (CGRP), and is strongly expressed by in several vascular tumours and types of gliomas [32-35]. Also of interest, we found over-expression of COL22A1, a member of the collagen protein family which specifically localizes to tissue junctions and acts as a cell adhesion ligand for skin epithelial cells and fibroblasts [36]. Taken together, these findings may suggest the potential role of CALCRL and COL22A1 as diagnostic markers for the identification of this GIST subgroup. This would need to be validated in a larger series of GIST.

We found that both quadruple ${ }^{\mathrm{WT}}$ GIST, in comparison with the other samples, strongly expressed several 
oncogenes, including ERG and NTRK2 (TrkB). This was confirmed by quantitative PCR. $E R G$ is a well-known member of the erythroblast transformation-specific (ETS) family of transcription factors, which function as transcriptional regulators [37]. ETS proteins are regulated by the mitogenic (RAS/MAPK) signalling transduction pathway, and play an important role in cell differentiation, proliferation, apoptosis and tissue remodelling [38]. There is evidence for an oncogenic role of ERG and the other ETS transcription factors in many human cancers, including sarcomas, prostate cancer, and acute myeloid leukemia, in most cases via chromosomal translocations [39-41]. More recently, it has been shown that the IHC detection of $E R G$ may be a useful marker for vascular tumors, prostate carcinoma and ERG-rearranged Ewing sarcoma [42-44]. Over-expression of NTRK2 (TrkB) in quadruple ${ }^{\mathrm{WT}}$ GIST is also of interest, as NTRK2 helps regulated neuronal cell function, including synaptic plasticity, differentiation, growth, survival, and motility [45]. It has also been shown that Trks regulate important processes in non-neuronal cells, contributing to the pathogenesis of several kinds of cancer, such as medullary thyroid carcinoma, prostate cancer, non-small cell lung cancer, head and neck squamous cell carcinoma and pancreatic cancer, in addition to tumors of neural origin [46-51]. Given the relevant biological role played by Trks in cancer, different small molecule inhibitors have been developed and evaluated both in mono-therapy and in combination with chemotherapy in phase 1 and 2 clinical trials [52-58].

To our knowledge, the over-expression of ERG and $\operatorname{TrkB}$ in GIST has not been previously reported. However, it is well known that ETV1, another member of ETS family, is highly expressed in GIST and certain subsets of ICC. ETV1 expression plays an important role in regulating the growth of KIT mutant GIST cell lines [59]. On the basis of our results, the overexpression of $E R G$ and $\operatorname{TrkB}$ seems to be a unique feature of the quadruple ${ }^{\mathrm{WT}}$ GIST, suggesting that it could play a relevant role in the pathogenesis of this subset of GIST. To translate these observations into clinical practice, the overexpression of both molecules could be investigated as diagnostic markers of quadruple ${ }^{\mathrm{WT}}$ GIST.

\section{Conclusions}

In conclusion, we report for the first time an integrated genomic picture of the quadruple ${ }^{\mathrm{WT}}$ GIST, using massively parallel sequencing and gene expression analyses, and have identified a unique subset of GIST among the family of the KIT/PDGFRA WT GIST [60]. The frequency of this GIST subset amongst the family of GIST will need to be defined in future studies as well as any unique clinical-pathological features of this GIST subset, including response to conventional GIST medical therapy. In addition, ongoing studies of ICC developmental biology may help identify the "normal" precursor cells that give rise to this unique GIST subgroup.

\section{Methods}

This study was approved by the institutional review board of Azienda Ospedaliero-Universitaria Policlinico S.Orsola-Malpighi, Bologna, Italy (approval number 113/ 2008/U/Tess). All patients provided written informed consent.

\section{Patients and tumor samples}

Fresh tissue specimens of GIST from 36 patients were collected during the surgical operation, snap-frozen in liquid nitrogen and stored at $-80^{\circ} \mathrm{C}$ until analysis. Patient's characteristics are listed in Table 1.

Whole-Transcriptome Paired-End RNA Sequencing was performed on 16 GIST, including $2 K I T^{\mathrm{WT}} / P D G F R A^{\mathrm{WT}}$ GIST patients without $S D H$-inactivating mutations (GIST 133 and GIST_127), $2 K^{K I} T^{\mathrm{WT}} / P D G F R A^{\mathrm{WT}}$ GIST patients harbouring SDHA-mutations (GIST_7 and GIST_10), and 12 KIT or PDGFRA mutated GIST patients (7 harboured exon 11 KIT mutations and 5 harboured exon 18 PDGFRA mutations).

Whole-genome gene expression analysis was performed on 9 of the above 16 GIST and extended to include an additional 20 GIST: $1 K I T^{W \mathrm{~T}} / P D G F R A^{\mathrm{WT}} / S D H A^{\mathrm{mut}}$ GIST and 19 KIT or PDGFRA mutated GIST, of which 13 harboured KIT mutations (12 in exon 11 and 2 in exon 9), and 5 harboured PDGFRA mutations (2 in exon 12, 1 in exon 14 and 2 in exon 18).

\section{SDH status}

$S D H$ protein expression status was evaluated by both immunohistochemistry (IHC) of $S D H B$ and $S D H$ subunits sequencing. IHC was performed on 4- $\mu \mathrm{m}$ sections of FFPE GIST tumor samples. Rabbit polyclonal antiSDHB (HPA002868, Sigma-Aldrich, St Louis, MO, USA, 1:800) antibody was used. The sections were deparaffinized, rehydrated, and subjected to the appropriate antigen retrieval treatment (SDHB: microwave heating in citrate buffer pH 6.0 at $1001 \mathrm{C}$ for $40 \mathrm{~min}$ ). After cooling at room temperature, the activity of endogenous peroxidises was inhibited using methanol/ $\mathrm{H} 2 \mathrm{O} 2(0.5 \% \mathrm{v} / \mathrm{v})$ for $20 \mathrm{~min}$. The sections were then washed in phosphatebuffered saline (PBS, pH 7.2-7.4) and incubated with the specific primary antibody overnight at room temperature. After that, the sections were washed in PBS and treated using the Novolink Polymer Detection System (Novocastra, Newcastle upon Tyne, UK) according to the manufacturer's instructions. Liver tissues (for $S D H B$ ) were used as positive controls. These tissues showed strong granular staining in the cytoplasm and mitochondria with both of the antibodies. 
Table 1 Patient's characteristic

\begin{tabular}{|c|c|c|c|c|c|c|c|}
\hline ID & Sex & Array & RNAseq & Age & Site & Disease status at diagnosis & KIT/PDGFRA/SDH mutational status \\
\hline GIST_133 & M & $x$ & $x$ & 57 & Duodenum & Localized & WT \\
\hline GIST_127 & $\mathrm{F}$ & $X$ & $x$ & 63 & lleum & Localized & WT \\
\hline GIST_07 & $\mathrm{F}$ & $x$ & $x$ & 27 & Stomach & Metastatic & SDHA exon 9 p.S384X \\
\hline \multirow[t]{2}{*}{ GIST_10 } & M & $x$ & $x$ & 29 & Stomach & Metastatic & SDHA exon 2 p.R31X; \\
\hline & & & & & & & SDHA exon 13 p.R589W \\
\hline GIST_188 & $\mathrm{F}$ & & $x$ & 57 & Duodenum & Metastatic & KIT exon 11 p.N564-L576 del + KIT exon 17 p.N822K \\
\hline GIST_174 & M & & $x$ & 59 & Stomach & Metastatic & KIT exon 11 p.N564_L576 del + KIT exon 17 p.N822K \\
\hline GIST_131 & M & $x$ & $x$ & 58 & Ileum & Localized & KIT exon 11 p.V569_Y578 del \\
\hline GIST_11 & M & $X$ & $x$ & 65 & Stomach & Localized & KIT exon 11 p.557-558 del \\
\hline GIST_134 & $\mathrm{F}$ & $x$ & $x$ & 65 & Stomach & Localized & KIT exon p.V559D \\
\hline GIST_124 & M & $x$ & $x$ & 70 & Stomach & Localized & KIT exon 11 p.1765-1766 ins \\
\hline GIST_150 & $\mathrm{F}$ & & $x$ & 55 & Stomach & Localized & KIT exon 11 p.P551_E554 del \\
\hline GIST_165 & M & & $x$ & 50 & Stomach & Localized & PDGFRA exon 18 p.D842V \\
\hline GIST_136 & M & $x$ & $x$ & 76 & Stomach & Localized & PDGFRA exon 18 p.D842V \\
\hline GIST_140 & $\mathrm{F}$ & & $x$ & 45 & Stomach & Localized & PDGFRA exon 18 p.D842V \\
\hline GIST_141 & M & & $x$ & 68 & Stomach & Localized & PDGFRA exon 18 p.D842V \\
\hline GIST_138 & $\mathrm{F}$ & & $x$ & 75 & Stomach & Localized & PDGFRA exon 18 p.D842V \\
\hline GIST_02 & $\mathrm{F}$ & $x$ & & 85 & Stomach & Localized & KIT exon 11 p.V560D \\
\hline GIST_04 & M & $x$ & & 79 & Stomach & Localized & KIT exon 9 p.AY502-503 ins \\
\hline GIST_05 & M & $x$ & & 68 & Stomach & Localized & PDGFRA exon 12 p.SPDGHE566-571RIQ \\
\hline GIST_08 & M & $X$ & & 62 & Stomach & Localized & KIT exon 11 p.V559D \\
\hline GIST_09 & M & $x$ & & 54 & Stomach & Localized & KIT exon 11 TLQPYDHKWEEFP 574-585 ins at P585 \\
\hline GIST_12 & $\mathrm{F}$ & $x$ & & 66 & Stomach & Localized & PDGFRA exon 14 p.K646E \\
\hline GIST_13 & M & $x$ & & 46 & Small intestine & Localized & KIT exon 11 p.V559D \\
\hline GIST_14 & M & $x$ & & 56 & Stomach & Localized & KIT exon 11 p.WK557-558del \\
\hline GIST_15 & $\mathrm{F}$ & $X$ & & 64 & Stomach & Localized & PDGFRA exon 18 DIMH p.842-845 DIMH del \\
\hline GIST_16 & $\mathrm{F}$ & $x$ & & 62 & Stomach & Localized & KIT exon 11 p.L576P \\
\hline GIST_20 & M & $x$ & & 38 & Small intestine & Metastatic & KIT exon 11 del MYEQW552-557 Z + KIT exon 18 A829P \\
\hline GIST_22 & $\mathrm{F}$ & $x$ & & 76 & Stomach & NA & PDGFRA exon 18 p.D842V \\
\hline GIST_23 & $\mathrm{F}$ & $x$ & & 47 & Stomach & NA & KIT exon 11 p.V559D \\
\hline GIST_24 & $\mathrm{F}$ & $x$ & & 18 & Stomach & Metastatic & SDHA exon 8 p.L349R fs*11 \\
\hline GIST_26 & M & $x$ & & 49 & Stomach & Localized & PDGFRA exon 12 p.V561D \\
\hline GIST_121 & M & $x$ & & 71 & Stomach & Localized & KIT exon 11 p.V559D \\
\hline GIST_125 & $\mathrm{F}$ & $x$ & & 48 & Stomach & Localized & KIT exon 11 p.W557R \\
\hline GIST_129 & M & $x$ & & 59 & Stomach & Localized & KIT exon11 p.Y553_V559 delins L \\
\hline GIST_130 & $\mathrm{F}$ & $x$ & & 79 & Stomach & Localized & KIT exon 9 p.A502-Y503 ins \\
\hline GIST_135 & $\mathrm{F}$ & $x$ & & 61 & Stomach & Localized & KIT exon 11 p.W557-E561 del \\
\hline
\end{tabular}

$S D H A$ gene exons [1-15], $S D H B$ gene exons [1-8], $S D H C$ (exon 1-6) and $S D H D$ (exon 1-4) were sequenced on fresh-frozen tumor specimens of $K I T^{\mathrm{WT}} / P D G F R A^{\mathrm{WT}}$ GIST patients by Sanger Sequencing method. DNA was extracted by the QIAmp DNA Mini kit (Qiagen, Milan, Italy) in accordance with manufacturer's directions. Each exon was amplified with Polymerase Chain Reaction (PCR) amplification using specific primer pairs designed with Primer Express 3.0 Software (Applied Biosystem) to amplify exons but not SDHA pseudo-genes located on chromosomes 3 and 5 . Then, PCR products were purified with the Qiaquick PCR purification kit (Qiagen, Milan, Italy) and sequenced on both strands using the Big Dye Terminator v1.1 Cycle Sequencing kit (Applied Biosystems). Sanger 
sequencing was performed on ABI 3730 Genetic Analyzer (Applied Biosystems).

\section{Whole-transcriptome paired-end RNA sequencing}

Total RNA was extracted from tumor specimens with RNeasy Mini Kit (Qiagen, Milan, Italy), then cDNA libraries were synthesized from $250 \mathrm{ng}$ total RNA with TruSeq RNA Sample Prep Kit v2 (Illumina, San Diego, CA) according to the manufacturer's recommendations. Sequencing by synthesis was performed on HiScanSQ sequencer (Illumina) at $75 \mathrm{bp}$ in paired-end mode. Whole-transcriptome sequencing yielded an average of 61 million mapped reads/patient, thus reaching an average coverage of $44 \mathrm{X}$. Two $S D H A^{\text {mut }}$ tumor specimens were previously analyzed by whole transcriptome sequencing at the Genome Sciences Centre (Vancouver, Canada) [9].

\section{Bioinformatic analysis}

After demultiplexing and FASTQ generation (both steps performed with Casava1.8, an application software specifically developed by Illumina), the paired-end reads quality were analyzed with the function fastx_quality_stats (part of FASTX Toolkit available at http://hannonlab.cshl.edu/fastx_toolkit/index.html). Based on these results we decided to trim each read of each sample at $74 \mathrm{bp}$ in order to maximize sequence quality. The pairedend reads were mapped with the pipeline TopHat/Bowtie [61] on human reference genome HG19, collected from UCSC Genome Browser (http://www.genome.ucsc.edu/). After the alignment procedure the BAM file obtained was manipulated with Samtools [62] in order to remove the optical/PCR duplicate, to sort and to index it.

The analysis of gene expression was performed in two steps: 1) the function htseq-count (Python package HTseq) [63] was adopted to count the number of reads mapped on known genes, included in the Ensembl release 72 annotation features (http://www.ensembl.org); 2) the differential expressed genes were evaluated using the R-Bioconductor package edger [64]. DeFuse, ChimeraScan and FusionMap packages were used to detect chimeric transcripts from RNA-seq data.

\section{Gene expression analysis}

RNA was extracted using RNeasy Mini Kit (Qiagen), quality-controlled and labeled as directed by the Affymetrix expression technical manual before hybridization to U133Plus 2.0 arrays. Gene expression data were quantified by the RMA algorithm, filtered and analyzed with supervised techniques by Limma modified $t$-test for the detection of differentially expressed genes. Differential expressed genes hierarchical clustering and Principal Component Analysis (PCA) were performed with Multiple Array Viewer (MEV available at http://www.tm4.org/mev.html).
The same software was used to represent the data in the Figure 3 and Figure 4. Gene expression data of KIT/ PDGFRA-mutated and SDHA-mutated samples were previously reported [30].

\section{Copy number analysis}

Genomic DNA was labelled and hybridized to SNP array Genome Wide SNP 6.0 (Affymetrix) following manufacturer's instructions. Quality control was performed by Contrast QC and MAPD calculation. Copy number analysis was performed by Genotyping Console and visualized with Chromosome Analysis Suite (ChAS) Software (Affymetrix). Hidden Markov Model algorithm was used to detect amplified and deleted segments with stringent parameters. To control for hyperfragmentation adjacent segments separated by $<50$ probes were combined into one single segment, and only segments $>100$ probes were considered.

\section{Quantitative PCR (qPCR)}

Total RNA was reverse transcribed using Transcriptor First Strand cDNA synthesis kit (Roche Applied Science, Monza, Italy) with oligo-dT primers, according to the manufacturer's guidelines. Gene-specific primers were designed with Primer Express 3.0 Software (Applied Biosystems) and qPCR was performed using FastStart Sybr Green (Roche) on the LightCycler 480 apparatus (Roche). DDCt method was used to quantify gene product levels relative to the GAPDH and ATP5B housekeeping genes. Significance was estimated by the Student's $t$ test: " $\mathrm{p}$-value $<0.05$; ${ }^{* * *} \mathrm{p}$-value $<0.01$, ${ }^{\text {***** }} \mathrm{p}$-value $<0.01$.

\section{Western blot}

Protein expression of NTRK2 was evaluated on 2 $K I T^{\mathrm{WT}} / P D G F R A^{\mathrm{WT}} / S D H^{\mathrm{WT}} / R A S-P^{\mathrm{WT}}$ GIST and $8 K I T$ or PDGFRA or SDH mutant GISTs, of which freshfrozen tissues were available. Tissue were disrupted in RIPA buffer (Sigma-Aldrich) supplemented with proteases inhibitors and lysed for $1 \mathrm{~h}$ with gentle agitation at $4^{\circ} \mathrm{C}$. Lysates were centrifuged at $13,000 \times g$ for $15 \mathrm{~min}$ at $4^{\circ} \mathrm{C}$ and supernatants were stored at $-80^{\circ} \mathrm{C}$. Protein concentrations were determined with the $\mathrm{BCA}$ protein assay (Pierce, Rockford, IL). Twenty micrograms of protein were resolved on a $8 \%$ SDS-PAGE gel and transferred onto polyvinylidene difluoride (PVDF) membranes. Nonspecific binding sites were blocked by incubation in blocking buffer (PBS containing 0.1\% Tween-20 with $5 \% \mathrm{w} / \mathrm{v}$ milk) for $1 \mathrm{~h}$ at room temperature. Membranes were incubated overnight at $4^{\circ} \mathrm{C}$, with the following primary antibodies: rabbit polyclonal TRKB antibody (ab18987 Abcam 1:500), and rabbit polyclonal $\beta$-Tubulin antibody (sc-9104 Santa Cruz Biotechnology, Santa Cruz, CA, 1:500). Then, membranes were washed and incubated with peroxidase conjugate secondary antibodies for $1 \mathrm{~h}$ at 
room temperature. Antigens were revealed using Enhanced Chemiluminescence Reaction (ECL Select, Amersham Pharmacia Biotech, Les Ulis, France).

\section{Nomenclature}

$K I T^{\mathrm{WT}}$ No mutations of KIT

PDGFRA ${ }^{\mathrm{WT}}$ No mutations of PDGFRA

$S D H^{\mathrm{WT}}$ No abnormalities of $S D H A / B / C / D$ protein

expression and/or gene mutation

$S D H A^{\mathrm{IHC}-}$ No expression of $S D H A$ protein

$S D H A^{\mathrm{IHC}+}$ Normal expression of SDHA protein

$S D H B^{\mathrm{IHC}-}$ No expression of $S D H B$ protein

$S D H B^{\mathrm{IHC}+}$ Normal expression of $S D H B$ protein

$S D H A^{\text {mut }}$ Mutation of $S D H A$ protein (homozygous or

compound heterozygote)

$S D H B^{\text {mut }}$ Mutation of $S D H B$ protein (homozygous or

compound heterozygote)

$S D H C^{\text {mut }}$ Mutation of SDHC protein (homozygous or compound heterozygote)

$S D H D^{\text {mut }}$ - Mutation of $S D H D$ protein (homozygous or compound heterozygote)

\section{Additional files}

Additional file 1: Table S1. NTRK2 protein overexpression in KIT $T^{\mathrm{WT}} /$ PDGFRA ${ }^{W T} / S D H^{W T} / R A S-P^{W T}$ GIST. Western blot immunostaining of NTRK2 was perfomed on proteins extracted from two quadruple ${ }^{W T}$ GIST and from eight PDGFRA or KIT or SDH mutated GIST. HL-60 cell line protein extract was used as positive control.

Additional file 2: Figure S1. NTRK2 protein overexpression in KIT ${ }^{\mathrm{WT}}$ / PDGFRA ${ }^{W T} / S D H^{W T} / R A S-P{ }^{W T}$ GIST. Western blot immunostaining of NTRK2 was perfomed on proteins extracted from two quadruple WT $_{\text {GIST } \text { and }}$ from eight PDGFRA or KIT or SDH mutated GIST. HL-60 cell line protein extract was used as positive control.

\section{Abbreviations}

CGRP: Calcitonin gene-related peptide; CSS: Carney-Stratakis Syndrome; CT: Carney Triad; DOG1: Discovered on gastrointestinal stromal tumours 1; ETS: Erythroblast transformation-specific; GIST: Gastrointestinal stromal tumors; ICCs: Cells of Cajal; IGF1R: Insulin growth factor 1 receptor; IHC: Immunohistochemistry; NF7: Neurofibromatosis type 1; PDGFRA: Platelet-derived growth factor receptor alpha; RAS-P: RAS-pathway; SDH: Succinate dehydrogenase; SNV: Single nucleotide variant; WT: Wild-type.

\section{Competing interests}

The authors declare that they have no competing interests.

\section{Authors' contributions}

MN: have made substantial contributions to conception and design of the study, interpretation of data and drafted the manuscript; AA: carried out the molecular genetic studies, the sequence alignment and have been involved in drafting the manuscript. MU: carried out the molecular genetic studies, the sequence alignment and have been involved in drafting the manuscript. VI: carried out the bioinformatic analysis and interpretation of data and have been involved in drafting the manuscript. DS: carried out the pathological analysis and the collection of samples. MCH: have been involved in revising the manuscript critically for important intellectual content and have given final approval of the version to be published. CLC: have been involved in revising the manuscript critically for important intellectual content and have given final approval of the version to be published. MS, AM and CL have helped to draft and revised the manuscript. GE: carried out the surgical collection of samples. GB: have been involved in revising the manuscript critically for important intellectual content and have given final approval of the version to be published. MAP: have made substantial contributions to conception and design of the study, interpretation of data and drafted the manuscript; All authors read and approved the final manuscript.

\section{Acknowledgments}

All staff of Bologna GIST Study Group: Annalisa Altimari, Claudio Ceccarelli, Paolo Castellucci, Fausto Catena, Monica Di Battista, Massimo Del Gaudio, Valerio Di Scioscio, Stefano Fanti, Michelangelo Fiorentino, Pietro Fusaroli, Lidia Gatto, Franco W. Grigioni, Elisa Gruppioni, Alessandra Maleddu, Maria Caterina Pallotti, Antonio Daniele Pinna, Paola Tommasetti, Maurizio Zompatori.

\section{Funding}

The present work was done with a financial contribution by Novartis Oncology, Italy, and with funds by My First Grant 2013, AIRC 2013.

\section{Author details}

${ }^{1}$ Department of Specialized, Experimental and Diagnostic Medicine, Sant'Orsola-Malpighi Hospital, University of Bologna, Via Massarenti 9, 40138 Bologna, Italy. " "Giorgio Prodi" Cancer Research Center, University of Bologna, Bologna, Italy. ${ }^{3}$ Pathology Unit, S. Orsola-Malpighi Hospital, University of Bologna, Bologna, Italy. ${ }^{4}$ Portland VA Medical Center and Knight Cancer Institute, and Division of Hematology and Oncology, Oregon Health \& Science University Portland, Portland, OR, USA. ${ }^{5}$ Department of Pathology and Knight Cancer Institute, Oregon Health \& Science University, Portland, OR, USA. ${ }^{6}$ Transplant, General and Emergency Surgery Department, S. Orsola-Malpighi Hospital, University of Bologna, Bologna, Italy.

Received: 23 January 2014 Accepted: 17 September 2014 Published: 20 September 2014

\section{References}

1. Corless $\mathrm{CL}$, Fletcher JA, Heinrich MC: Biology of gastrointestinal stromal tumors. J Clin Oncol 2004, 22:3813-3825.

2. Janeway KA, Pappo AS: Pediatric gastrointestinal stromal tumor. Hematol Oncol Clin North Am 2009, 23:15-34

3. Heinrich MC, Corless CL, Demetri GD, Blanke CD, von Mehren M, Joensuu $H$, McGreevey LS, Chen CJ, Van den Abbeele AD, Druker BJ, Kiese B, Eisenberg B, Roberts PJ, Singer S, Fletcher CD, Silberman S, Dimitrijevic S, Fletcher JA: Kinase mutations and imatinib response in patients with metastatic gastrointestinal stromal tumor. J Clin Oncol 2003, 21:4342-4349.

4. Debiec-Rychter M, Sciot R, Le Cesne A, Schlemmer M, Hohenberger P, van Oosterom AT, Blay JY, Leyvraz S, Stul M, Casali PG, Zalcberg J, Verweij J, Van Glabbeke M, Hagemeijer A, Judson I, EORTC Soft Tissue and Bone Sarcoma Group; Italian Sarcoma Group; Australasian Gastrolntestinal Trials Group: KIT mutations and dose selection for imatinib in patients with advanced gastrointestinal stromal tumours. Eur J Cancer 2006, 42:1093-1103.

5. Heinrich MC, Owzar K, Corless CL, Hollis D, Borden EC, Fletcher CD, Ryan CW, von Mehren M, Blanke CD, Rankin C, Benjamin RS, Bramwell VH, Demetri GD, Bertagnolli MM, Fletcher JA: Correlation of kinase genotype and clinical outcome in the North American Intergroup Phase III Trial of imatinib mesylate for treatment of advanced gastrointestinal stromal tumor: CALGB 150105 Study by Cancer and Leukemia Group B and Southwest Oncology Group. J Clin Oncol 2008, 26:5360-5367.

6. Gill AJ, Chou A, Vilain R, Clarkson A, Lui M, Jin R, Tobias V, Samra J, Goldstein D, Smith C, Sioson L, Parker N, Smith RC, Sywak M, Sidhu SB, Wyatt JM, Robinson BG, Eckstein RP, Benn DE, Clifton-Bligh RJ: Immunohistochemistry for SDHB divides gastrointestinal stromal tumors (GISTs) into 2 distinct types. Am J Surg Pathol 2010, 34:636-644.

7. Miettinen M, Wang ZF, Sarlomo-Rikala M, Osuch C, Rutkowski P, Lasota J: Succinate dehydrogenase-deficient GISTs: a clinicopathologic, immunohistochemical, and molecular genetic study of 66 gastric GISTs with predilection to young age. Am J Surg Pathol 2011, 35:1712-1721.

8. Janeway KA, Kim SY, Lodish M, Nosé V, Rustin P, Gaal J, Dahia PL, Liegl B, Ball ER, Raygada M, Lai AH, Kelly L, Hornick JL, NIH Pediatric and Wild-Type GIST Clinic, O'Sullivan M, de Krijger RR, Dinjens WN, Demetri GD, Antonescu CR, Fletcher JA, Helman L, Stratakis CA: Defects in succinate dehydrogenase in gastrointestinal stromal tumors lacking KIT and PDGFRA mutations. ProC Natl Acad Sci U S A 2011, 108:314-318. 
9. Pantaleo MA, Astolfi A, Indio V, Moore R, Thiessen N, Heinrich MC, Gnocchi C, Santini D, Catena F, Formica S, Martelli PL, Casadio R, Pession A, Biasco G: SDHA loss-of-function mutations in KIT-PDGFRA wild-type gastrointestinal stromal tumors identified by massively parallel sequencing. J Natl Cancer Inst 2011, 103:983-987.

10. Pantaleo MA, Nannini M, Astolfi A, Biasco G, GIST Study Group Bologna: A distinct pediatric-type gastrointestinal stromal tumor in adults: potential role of succinate dehydrogenase subunit A mutations. Am J Surg Pathol 2011, 35:1750-1752.

11. Italiano A, Chen CL, Sung YS, Singer S, DeMatteo RP, LaQuaglia MP, Besmer $P$, Socci N, Antonescu CR: SDHA loss of function mutations in a subset of young adult wild-type gastrointestinal stromal tumors. BMC Cancer 2012, 12:408.

12. Wagner AJ, Remillard SP, Zhang YX, Doyle LA, George S, Hornick JL: Loss of expression of SDHA predicts SDHA mutations in gastrointestinal stromal tumors. Mod Pathol 2013, 26:289-294.

13. Dwight T, Benn DE, Clarkson A, Vilain R, Lipton L, Robinson BG, Clifton-Bligh $\mathrm{RJ}$, Gill AJ: Loss of SDHA expression identifies SDHA mutations in succinate dehydrogenase-deficient gastrointestinal stromal tumors. Am J Surg Pathol 2013, 37:226-233.

14. Oudijk L, Gaal J, Korpershoek E, van Nederveen FH, Kelly L, Schiavon G, Verweij J, Mathijssen RH, den Bakker MA, Oldenburg RA, van Loon RL, O'Sullivan MJ, de Krijger RR, Dinjens WN: SDHA mutations in adult and pediatric wild-type gastrointestinal stromal tumors. Mod Pathol 2013, 26:456-463

15. Miettinen M, Killian JK, Wang ZF, Lasota J, Lau C, Jones L, Walker R, Pineda M, Zhu YJ, Kim SY, Helman L, Meltzer P: Immunohistochemical loss of succinate dehydrogenase subunit $\mathrm{A}(\mathrm{SDHA})$ in gastrointestinal stromal tumors (GISTs) signals SDHA germline mutation. Am J Surg Pathol 2013, 37:234-240.

16. Pantaleo MA, Astolfi A, Urbini M, Nannini M, Paterini P, Indio V, Saponara M, Formica S, Ceccarelli C, Casadio R, Rossi G, Bertolini F, Santini D, Pirini MG, Fiorentino M, Basso U, Biasco G, on behalf of GIST Study Group, University of Bologna, Bologna, Italy: Analysis of all subunits, SDHA, SDHB, SDHC, SDHD, of the succinate dehydrogenase complex in KIT/PDGFRA wildtype GIST. Eur J Hum Genet 2013. Epub online before print.

17. Rege TA, Wagner AJ, Corless CL, Heinrich MC, Hornick JL: "Pediatric-type" gastrointestinal stromal tumors in adults: distinctive histology predicts genotype and clinical behavior. Am J Surg Pathol 2011, 35:495-504.

18. Chou A, Chen J, Clarkson A, Samra JS, Clifton-Bligh RJ, Hugh TJ, Gill AJ: Succinate dehydrogenase-deficient GISTs are characterized by IGF1R overexpression. Mod Pathol 2012, 25:1307-1313.

19. Nannini M, Astolfi A, Paterini P, Urbini M, Santini D, Catena F, Indio V, Casadio R, Pinna AD, Biasco G, Pantaleo MA: Expression of IGF-1 receptor in KIT/PDGF receptor-a wild-type gastrointestinal stromal tumors with succinate dehydrogenase complex dysfunction. Future Oncol 2013 9:121-126.

20. Belinsky MG, Rink L, Flieder DB, Jahromi MS, Schiffman JD, Godwin AK, Mehren M: Overexpression of insulin-like growth factor 1 receptor and frequent mutational inactivation of SDHA in wild-type SDHB-negative gastrointestinal stromal tumors. Genes Chromosomes Cancer 2013, 52:214-224

21. Lasota J, Wang Z, Kim SY, Helman L, Miettinen M: Expression of the receptor for type I insulin-like growth factor (IGF1R) in gastrointestinal stromal tumors: an immunohistochemical study of 1078 cases with diagnostic and therapeutic implications. Am J Surg Pathol 2013, 37:114-119.

22. McWhinney SR, Pasini B, Stratakis CA: Familial gastrointestinal stromal tumors and germ-line mutations. N Engl J Med 2007, 357:1054-1056.

23. Pasini B, McWhinney SR, Bei T, Matyakhina L, Stergiopoulos S, Muchow M, Boikos SA, Ferrando B, Pacak K, Assie G, Baudin E, Chompret A, Ellison JW, Briere JJ, Rustin P, Gimenez-Roqueplo AP, Eng C, Carney JA, Stratakis CA: Clinical and molecular genetics of patients with the Carney-Stratakis syndrome and germline mutations of the genes coding for the succinate dehydrogenase subunits SDHB, SDHC, and SDHD. Eur J Hum Genet 2008, 16:79-88.

24. Zhang L, Smyrk TC, Young WF Jr, Stratakis CA, Carney JA: Gastric stromal tumors in Carney triad are different clinically, pathologically, and behaviourally from sporadic gastric gastrointestinal stromal tumors: findings in 104 cases. Am J Surg Pathol 2010, 34:53-64.

25. Bajor J: Gastrointestinal stromal tumors in patients with type 1 neurofibromatosis. Clin Exp Med J 2009, 3:247-254.
26. Agaram NP, Wong GC, Guo T, Maki RG, Singer S, Dematteo RP, Besmer $P$, Antonescu CR: Novel V600E BRAF mutations in imatinib-naive and imatinib-resistant gastrointestinal stromal tumors. Genes Chromosomes Cancer 2008, 47:853-859.

27. Hostein I, Faur N, Primois C, Boury F, Denard J, Emile JF, Bringuier PP, Scoazec JY, Coindre JM: BRAF mutation status in gastrointestinal stromal tumors. Am J Clin Pathol 2010, 133:141-148.

28. Daniels M, Lurkin I, Pauli R, Erbstösser E, Hildebrandt U, Hellwig K, Zschille U, Lüders P, Krüger G, Knolle J, Stengel B, Prall F, Hertel K, Lobeck H, Popp B, Theissig F, Wünsch P, Zwarthoff E, Agaimy A, Schneider-Stock R: Spectrum of KIT/PDGFRA/BRAF mutations and Phosphatidylinositol-3-Kinase pathway gene alterations in gastrointestinal stromal tumors (GIST). Cancer Lett 2011, 312:43-54.

29. Pantaleo MA, Nannin M, Corless CL, Heinrich MC: Quadruple wild-type (WT) GIST: defining the subset of GISTs that lack abnormalities of KIT, PDGFRA, SDH, and the RAS signalling pathway. Cancer Med 2014. in press.

30. Pantaleo MA, Astolfi A, Nannini M, Ceccarelli C, Formica S, Santini D, Heinrich MC, Corless C, Dei Tos AP, Paterini P, Catena F, Maleddu A, Saponara M, Di Battista M, Biasco G: Differential expression of neural markers in KIT and PDGFRA wild-type gastrointestinal stromal tumours. Histopathology 2011, 59:1071-1080.

31. Beadling C, Patterson J, Justusson E, Nelson D, Pantaleo MA, Hornick JL, Chacón M, Corless CL, Heinrich MC: Gene expression of the IGF pathway family distinguishes subsets of gastrointestinal stromal tumors wild type for KIT and PDGFRA. Cancer Med 2013, 2:21-31.

32. Muff R, Born W, Fischer JA: Calcitonin, calcitonin gene-related peptide, adrenomedullin and amylin: homologous peptides, separate receptors and overlapping biological actions. Eur J Endocrinol 1995, 133:17-20.

33. Hagner S, Stahl U, Grimm T, Stürzl M, Lang RE: Expression of calcitonin receptor-like receptor in human vascular tumours. J Clin Pathol 2006, 59:1104-1107

34. Mennel HD, Hallier-Neelsen M, Hagner S, Benes L: Two novel cell specific receptor proteins, CRLR and CD 117 in human glial tumors. Clin Neuropathol 2006, 25:107-114.

35. Benes L, Kappus C, McGregor GP, Bertalanffy H, Mennel HD, Hagner S: The immunohistochemical expression of calcitonin receptor-like receptor (CRLR) in human gliomas. J Clin Pathol 2004, 57:172-176.

36. Koch M, Schulze J, Hansen U, Ashwodt T, Keene DR, Brunken WJ, Burgeson RE, Bruckner P, Bruckner-Tuderman L: A novel marker of tissue junctions, collagen XXII. J Biol Chem 2004, 279:22514-22521.

37. Reddy ES, Rao VN, Papas TS: The erg gene: a human gene related to the ets oncogene. Proc Natl Acad Sci U S A 1987, 84:6131-6135.

38. Hart AH, Corrick CM, Tymms MJ, Hertzog PJ, Kola I: Human ERG is a proto-oncogene with mitogenic and transforming activity. Oncogene 1995, 10:1423-1430.

39. Sorensen PH, Lessnick SL, Lopez-Terrada D, Liu XF, Triche TJ, Denny CT: A second Ewing's sarcoma translocation, $t(21 ; 22)$, fuses the EWS gene to another ETS-family transcription factor, ERG. Nat Genet 1994, 6:146-151.

40. Sorensen PH, Lessnick SL, Lopez-Terrada D, Liu XF, Triche TJ, Denny CT: Recurrent fusion of TMPRSS2 and ETS transcription factor genes in prostate cancer. Science 2005, 310:644-648.

41. Martens $\mathrm{JH}$ : Acute myeloid leukemia: a central role for the ETS factor ERG. Int J Biochem Cell Biol 2011, 43:1413-1416.

42. Miettinen M, Wang ZF, Paetau A, Tan SH, Dobi A, Srivastava S, Sesterhenn I: ERG transcription factor as an immunohistochemical marker for vascular endothelial tumors and prostatic carcinoma. Am J Surg Pathol 2011, 35:432-441

43. Wang WL, Patel NR, Caragea M, Hogendoorn PC, López-Terrada D, Hornick $J$, Lazar AJ: Expression of ERG, an Ets family transcription factor, identifies ERG-rearranged Ewing sarcoma. Mod Pathol 2012, 25:1378-1383.

44. Miettinen M, Wang Z, Sarlomo-Rikala M, Abdullaev Z, Pack SD, Fetsch JF: ERG expression in epithelioid sarcoma: a diagnostic pitfall. Am J Surg Pathol 2013, 37:1580-1585.

45. Thiele CJ, Li Z, McKee AE: On Trk-the TrkB signal transduction pathway is an increasingly important target in cancer biology. Clin Cancer Res 2009, 15:5962-5967.

46. Brodeur GM, Nakagawara A, Yamashiro DJ, Ikegaki N, Liu XG, Azar CG, Lee $C P$, Evans AE: Expression of TrkA, TrkB and TrkC in human neuroblastomas. J Neurooncol 1997, 31:49-55.

47. McGregor LM, McCune BK, Graff JR, McDowell PR, Romans KE, Yancopoulos GD, Ball DW, Baylin SB, Nelkin BD: Roles of trk family neurotrophin 
receptors in medullary thyroid carcinoma development and progression. Proc Natl Acad Sci U S A 1999, 96:4540-4545.

48. Satoh F, Mimata H, Nomura T, Fujita Y, Shin T, Sakamoto S, Hamada Y, Nomura Y: Autocrine expression of neurotrophins and their receptors in prostate cancer. Int J Urol 2001, 8:S28-S34.

49. Harada T, Yatabe Y, Takeshita M, Koga T, Yano T, Wang Y, Giaccone G: Role and relevance of TrkB mutations and expression in non-small cell lung cancer. Clin Cancer Res 2011, 17:2638-2645.

50. Kupferman ME, Jiffar T, El-Naggar A, Yilmaz T, Zhou G, Xie T, Feng L, Wang J, Holsinger FC, Yu D, Myers JN: TrkB induces EMT and has a key role in invasion of head and neck squamous cell carcinoma. Oncogene 2010, 29:2047-2059.

51. Sclabas GM, Fujioka S, Schmidt C, Li Z, Frederick WA, Yang W, Yokoi K, Evans DB, Abbruzzese JL, Hess KR, Zhang W, Fidler IJ, Chiao PJ: Overexpression of tropomysin-related kinase B in metastatic human pancreatic cancer cells. Clin Cancer Res 2005, 11:440-449.

52. Camoratto AM, Jani JP, Angeles TS, Maroney AC, Sanders CY, Murakata C, Neff NT, Vaught JL, Isaacs JT, Dionne CA: CEP-751 inhibits TRK receptor tyrosine kinase activity in vitro exhibits anti-tumor activity. Int I Cancer 1997, 72:673-679.

53. Miknyoczki SJ, Dionne CA, Klein-Szanto AJ, Ruggeri BA: The novel Trk receptor tyrosine kinase inhibitor CEP-701 (KT-5555) exhibits antitumor efficacy against human pancreatic carcinoma (Panc1) xenograft growth and in vivo invasiveness. Ann N YAcad Sci 1999, 880:252-262.

54. Evans AE, Kisselbach KD, Yamashiro DJ, Ikegaki N, Camoratto AM, Dionne CA, Brodeur GM: Antitumor activity of CEP-751 (KT-6587) on human neuroblastoma and medulloblastoma xenografts. Clin Cancer Res 1999, 5:3594-3602.

55. Strock CJ, Park J, Rosen M, Dionne C, Ruggeri B, Jones-Bolin S, Denmeade SR, Ball DW, Nelkin BD: CEP-701 and CEP-751 inhibit constitutively activated RET tyrosine kinase activity and block medullary thyroid carcinoma cell growth. Cancer Res 2003, 63:5559-5563.

56. Marshall JL, Kindler H, Deeken J, Bhargava P, Vogelzang NJ, Rizvi N, Luhtala T, Boylan S, Dordal M, Robertson P, Hawkins MJ, Ratain MJ: Phase I trial of orallyadministeredCEP-701, anovelneurotrophin receptor-linked tyrosine kinase inhibitor. Invest New Drugs 2005, 23:31-37.

57. Wang T, Lamb ML, Scott DA, Wang H, Block MH, Lyne PD, Lee JW, Davies AM, Zhang HJ, Zhu Y, Gu F, Han Y, Wang B, Mohr PJ, Kaus RJ, Josey JA, Hoffmann E, Thress K, Macintyre T, Wang H, Omer CA, Yu D: Identification of 4-aminopyrazolylpyrimidines as potent inhibitors of Trk kinases. J Med Chem 2008, 51:4672-4684.

58. Chan E, Mulkerin D, Rothenberg M, Holen KD, Lockhart AC, Thomas J, Berlin J: A phase I trial of CEP-701 + gemcitabine in patients with advanced adenocarcinoma of the pancreas. Invest New Drugs 2008, 26:241-247.

59. Chi P, Chen Y, Zhang L, Guo X, Wongvipat J, Shamu T, Fletcher JA, Dewell $S$, Maki RG, Zheng D, Antonescu CR, Allis CD, Sawyers CL: ETV1 is a lineage survival factor that cooperates with KIT in gastrointestinal stromal tumours. Nature 2010, 467:849-853.

60. Nannini M, Biasco G, Astolfi A, Pantaleo MA: An overview on molecular biology of KIT/PDGFRA wild type (WT) gastrointestinal stromal tumours (GIST). J Med Genet 2013, 50:653-661.

61. Trapnell C, Pachter L, Salzberg SL: TopHat: discovering splice junctions with RNA-Seq. Bioinformatics 2009, 9:1105-1111.

62. Li H, Handsaker B, Wysoker A, Fennell T, Ruan J, Homer N, Marth G, Abecasis G, Durbin R, 1000 Genome Project Data Processing Subgroup: The Sequence Alignment/Map format and SAMtools. Bioinformatics 2009, 25:2078-2079.

63. Anders $\mathrm{S}$, Huber W: Differential expression analysis for sequence count data. Genome Biol 2010, 11:R106.

64. Robinson MD, McCarthy DJ, Smyth GK: edgeR: a Bioconductor package for differential expression analysis of digital gene expression data. Bioinformatics 2010, 26:139-140.

doi:10.1186/1471-2407-14-685

Cite this article as: Nannini et al: Integrated genomic study of quadruple-WT GIST (KIT/PDGFRA/SDH/RAS pathway wild-type GIST). BMC Cancer 2014 14:685.

\section{Submit your next manuscript to BioMed Central and take full advantage of:}

- Convenient online submission

- Thorough peer review

- No space constraints or color figure charges

- Immediate publication on acceptance

- Inclusion in PubMed, CAS, Scopus and Google Scholar

- Research which is freely available for redistribution

Submit your manuscript at www.biomedcentral.com/submit
C Biomed Central 